\title{
Report on the Undergraduate Awards Global Summit (2)
}

\author{
NATALIA A. BEGHIN
}

Natalia Beghin was the overall winner in the Politics and International Relations category of the 2016 international Undergraduate Awards for her paper 'Perverting the Panopticon: Feminism, Peace, and the Prospect of a "New Totalitarianism"' and attended the Prize Ceremony and Global Summit in Dublin, Ireland. Her paper has been published in The Undergraduate Journal.

It was an honour and a privilege to have been given the opportunity to participate in the 2016 Undergraduate Awards Summit as a Global Winner. Having attended the previous year as a Highly Commended entrant in both the Economic and Philosophy/Theology categories, I was excited for the conference that lay ahead, knowing that I was sure to meet friends old and new, have my world view (and circadian rhythm!) challenged and, most of all, enjoy every minute!

This year's event did not disappoint. But it was to have an even bigger impact on my experience, both academic and personal; the Summit couldn't have been more timely given the world events unfolding during our time in Dublin. To many of the conference participants, the new political reality that dawned as the US presidential election outcome became known reinforced the urgency we all felt to share our research, stories and opinions, and work hard to open ourselves up to those of others. Out of such collaboration came the testaments of a student who has created a synthetic heart for surgeons to practice with, another who managed to gain political asylum by bartering his paintings for safety, another who gained significant philosophical ground in establishing a case for tangible existence, and much more.

My research combined my passions for political theory and philosophy to propose a pathway through which peace might be attained in both the international and domestic spheres. I accomplished this by conducting a reformist analysis of the scholarship of Johan Galtung the Norwegian sociologist, and Michel Foucault, the French philosopher and historian, with reference to the work of the structuralist feminist scholar Judith Butler.

Butler proposed that one's gender is established not by endogenous qualities attributed by biological sex, but rather through a cyclical process of mimicry, or 'acts'. ${ }^{1}$ People engage in such behaviour as a result of gender and power relations

1 Judith Butler, Gender Trouble, (New York, Routledge, 2009), 35. 
that are antecedent to consciousness of gender as a construction. ${ }^{2}$ Therefore, the process of acting in ways that are commensurate with our assigned genders paradoxically denies women in particular the opportunity to escape the very structures of domination feminists wish to amend. ${ }^{3}$ I argue that such poststructuralist feminist scholarship has wider implications for Galtungian conceptions of peace (as a phenomenon whose existence is largely determined by structural expression and cause) and Foucauldian power/knowledge theory (which envisages history as an ongoing process of tension between the epistemically empowered and disempowered, expressed in primarily physical ways). ${ }^{4}$

My contention in light of such conclusions was twofold. First, a susceptibility to being considered 'vulnerable' to such machinations of power, or, as Butler would say, 'greivable' is the only knowledge claim (institutionalised or otherwise) that can be made concerning other people and their existence as actors in the world we share with one another. ${ }^{5}$ Second, rather than consider Foucault's conception of cyclical domination in negative terms, we can use processes of resistance (or what he terms 'genealogy') to reformulate new relations of power. ${ }^{6}$ In effect, we have been mistaken to believe that 'liberation' from subversive relations is the only means by which peacefulness may be attained, and instead it is more productive to work with an appreciation of the persistence of power structures, rather than wishing them away. This is why I called my paper a 'totalitarianism of peace' because the establishment of gender-equal and non-violent relations does not guarantee that they will not be monolithic or oppressive to some agents. By their nature, they will always necessitate the creation of a new balance of supremacy and subordination in order to be 'successful'.

Since the conference, I have been continuing my work on making such a totalitarianism more explicit, investigating constructivist notions of 'denaturalisation' to establish a clearer blueprint for what such a process might tangibly entail.

\section{Bibliography}

Beghin, Natalia. (2017). 'Perverting the Panopticon: Feminism, Peace, and the Prospect of a "New Totalitarianism". The Undergraduate Journal, 8, 225-234.

\footnotetext{
2 Ibid., 76.

Ibid., 42.

Johan Galtung and Deitrich Fischer, Johan Galtung: Pioneer of Peace Research, (New York, Springer, 2013), 47; Michel Foucault, Discipline and Punish: The Birth of the Prison, (New York, Vintage Books, 1977), 137.

5 Jill Stauffer and Judith Butler, 'Peace is Resistance to the Terrible Satisfactions of War: An Interview with Judith Butler' Qui Parle, vol. 14, no. 1 (2003), 102.

6 Michel Foucault, 'On the Genealogy of ethics: An Overview of Work in Progress' in The Foucault Reader, ed. P. Rabinow (New York, Pantheon, 1984), 169.
} 
Butler, Judith. (2009). Gender Trouble. New York, NY: Routledge.

Foucault, Michel. (1984). 'On the Genealogy of Ethics: An Overview of Work in Progress'. In P. Rabinow (ed.), The Foucault Reader. New York, NY: Pantheon.

Foucault, Michel. (1977). Discipline and Punish: The Birth of the Prison. New York, NY: Vintage Books.

Galtung, Johan \& Fischer, Deitrich. (2013). Johan Galtung: Pioneer of Peace Research. New York, NY: Springer. doi.org/10.1007/978-3-642-32481-9

Stauffer, Jill \& Butler, Judith. (2003). 'Peace is Resistance to the Terrible Satisfactions of War: An Interview with Judith Butler'. Qui Parle, 14(1), 99-121. doi: 10.1215/quiparle.14.1.99 
This text is taken from The ANU Undergraduate Research Journal, Volume Eight, 2016, edited by Daniel McKay, published 2017 by ANU eView, The Australian National University, Canberra, Australia.

dx.doi.org/10.22459/AURJ.08.2016.02 